\title{
AMERICAN MUSEUM NOVITATES
}

Number 3902,8 pp.

June 21,2018

\section{Occurrence of Dipleura dekayi Green, 1832 (Trilobita; Homalonotidae) in the Devonian of Colombia}

\author{
MARIA DA GLORIA PIRES DE CARVALHO ${ }^{1}$
}

\begin{abstract}
A large and almost complete dorsal exoskeleton of a homalonotid trilobite from the Middle Devonian of Colombia (Floresta Formation) is described and referred to Dipleura dekayi Green, 1832, confirming prior suggestions of biogeographical affinity between Colombia and the North Eastern Americas Realm during Devonian times.
\end{abstract}

Keywords: Trilobita (Homalonotidae), Devonian, Colombia

\section{INTRODUCTION}

In 1935, Axel A. Olsson and Paul Dickey discovered a Colombian Devonian assemblage that was described by Caster (1939), who considered it to be essentially equivalent to North American early Onandagan and Oriskanian faunas. Many subsequent authors have agreed with Caster $(1939,1942)$ that the Devonian marine megafauna (mainly brachiopods, trilobites, and corals) from Colombia is more closely related to the North Eastern Americas Realm (NEAR) than the endemic South American Malvinokaffric Realm (McNair, 1940; Morales, 1965; Forero, 1970; Boucot, 1975; Boucot and Gray, 1979; Cooper, 1982; Barrett, 1988; Barrett and Isaacson, 1988). This faunal similarity may reflect narrowing of the Rheic Ocean during the Devonian, with northern South America (including Colombia and Venezuela) facing Laurussia on either side of the ocean (Nance and Linnemann, 2008). Nevertheless, Morzadec et al. (2015) sug-

${ }^{1}$ Division of Paleontology, American Museum of Natural History. 


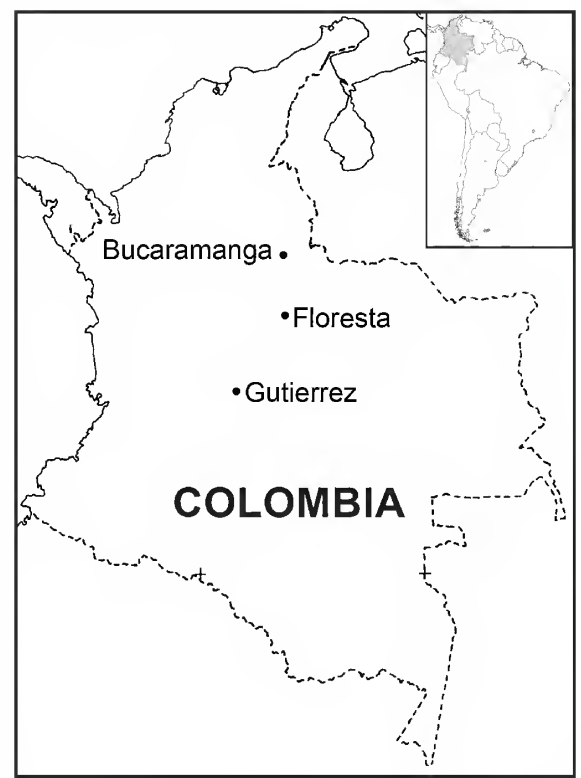

FIG. 1. Map of South America, showing Colombia and the cities of Gutierrez, Floresta, and Bucaramanga. gested that there was limited faunal exchange between Colombia and the Malvinokaffric Realm, based on the occurrence of calmoniids in the Floresta Formation.

Brachiopods and bryozoans are very abundant within the invertebrate assemblage, whereas other groups are not so well represented. Regarding the trilobites, Caster (1939) recognized and figured four genera, belonging to the families Aulacopleuridae (?Cyphaspis sp), Homalonotidae (?Homalonotus sp.), Phacopidae (Phacops cf. salteri Kozłowski [1923]), and Dalmanitidae (?Dalmanites cf. patacamayaensis Kozłowski). Unfortunately, the poor state of preservation did not permit Caster to give more accurate identifications of the material. A comprehensive revision of the trilobites from the Floresta Formation was presented by Morzadec et al. (2015), including a homalonotid (represented only by two cranidia) referred to Dipleura cf. dekayi. A more complete specimen is described here and can be referred more confidently to Dipleura dekayi Green, confirming the occurrence of this species outside North America.

\section{GEOLOGICAL SETTING}

Barrett (1988) summarized the Devonian System in Colombia as consisting of clastic rocks, mainly shale, siltstone, and subordinate sandstone lithologies, but also recognized that different facies or stratigraphic sequences existed between the south of the Floresta area (Bata-Farallones and Gutierrez areas) and the north (Bucamaranga area). Morzadec et al. (2015: 2) presented the most recent and complete stratigraphy of the Floresta Formation, which spans the late Emsian to Givetian interval, based on marine invertebrates (mainly brachiopods and trilobites). The level in which Dipleura occurs is considered to be Middle Devonian age (Givetian; Morzadec, 2015: 3), and the presence of $D$. dekayi provides an important confirmation of this.

\section{MATERIAL AND METHODS}

The Colombia specimens of Dipleura dekayi studied here were collected from the Floresta Formation near the village of Gutierrez, south of Floresta (fig. 1), by geologists from the Shell Oil Co. while searching for oil in Colombia. No more information on the locality is available. The material consist of an internal mold of one large and almost complete dorsal exoskeleton preserved in a concretion, and counterpart molds of a fragmentary cephalon together with three articulated but displaced thoracic segments. They were coated with magnesium oxide prior to photography. The specimens studied in this paper are deposited in the Cincinnati Museum Center Invertebrate Paleontology, Geier Collection and Research Facility, Cincinnati (CMCIP). 


\section{SYSTEMATIC PALEONTOLOGY}

Order PHACOPIDA Salter, 1864

Suborder CALYMENINA Swinnerton, 1915

Superfamily CALYMENOIDEA Milne Edwards, 1840

Family HOMALONOTIDAE Chapman, 1890

Subfamily HOMALONOTINAE Chapman, 1890

Genus Dipleura Green, 1832

Type Species (by monotypy): Dipleura dekayi Green, 1832, Middle Devonian Hamilton Group, New York State.

Stratigraphic Range: Upper Silurian (mid-Ludlow) to Middle Devonian (Givetian).

Generic Diagnosis: See Sandford, 2005: 29.

Dipleura dekayi Green, 1832

Figures 2A, B, 3A-D

OcCurRence: Locality of Gutierrez, Colombia, upper level of Floresta Formation, Middle Devonian (Givetian).

MATERIAL: CMCIP 77138: internal mold of an almost complete specimen, preserved in a concretion. CMCIP 77139: internal mold of incomplete cephalon associated with parts of three thoracic segments. CMCIP 77140: incomplete counterpart of 77139, showing external mold of the cephalon, plus parts of two thoracic segments.

\section{DESCRIPTION}

The most complete specimen (CMCIP 77138) has a preserved length of approximately $17.90 \mathrm{~cm}$ (the anterior rostral plate is missing as well as the tip of the pygidium).

Cephalon subtriangular in outline, gently convex. Glabella is well defined, trapezoidal, weakly convex longitudinally and transversally, without lobation. Glabella $34.9 \mathrm{~mm}$ long (sag.), without the occipital ring; slightly wider posteriorly $(28.0 \mathrm{~mm})$ than anteriorly $(27.0 \mathrm{~mm})$. It is densely covered with small granules. Axial furrow is shallow and wide, subparallel and concave slightly. In lateral view, occipital ring lies below level of the glabella; it is clearly defined anteriorly by moderately long (sag.) occipital furrow, nearly straight (tr.) but weakly convex forward adaxially. Length of axial ring (sag.) is $3.5 \mathrm{~mm}$. Palpebral area is swollen almost the same level of the highest level of the glabella, with the palpebral lobe bearing a small eye, located behind the midlength of the glabella.

Thorax with 13 segments. The axis is broad (tr.), weakly separated from the pleural field by an indistinct axial furrow, defined by small depressions situated distally in the axial rings where they join the pleurae. The axial rings are separated from the articulating half ring by a 


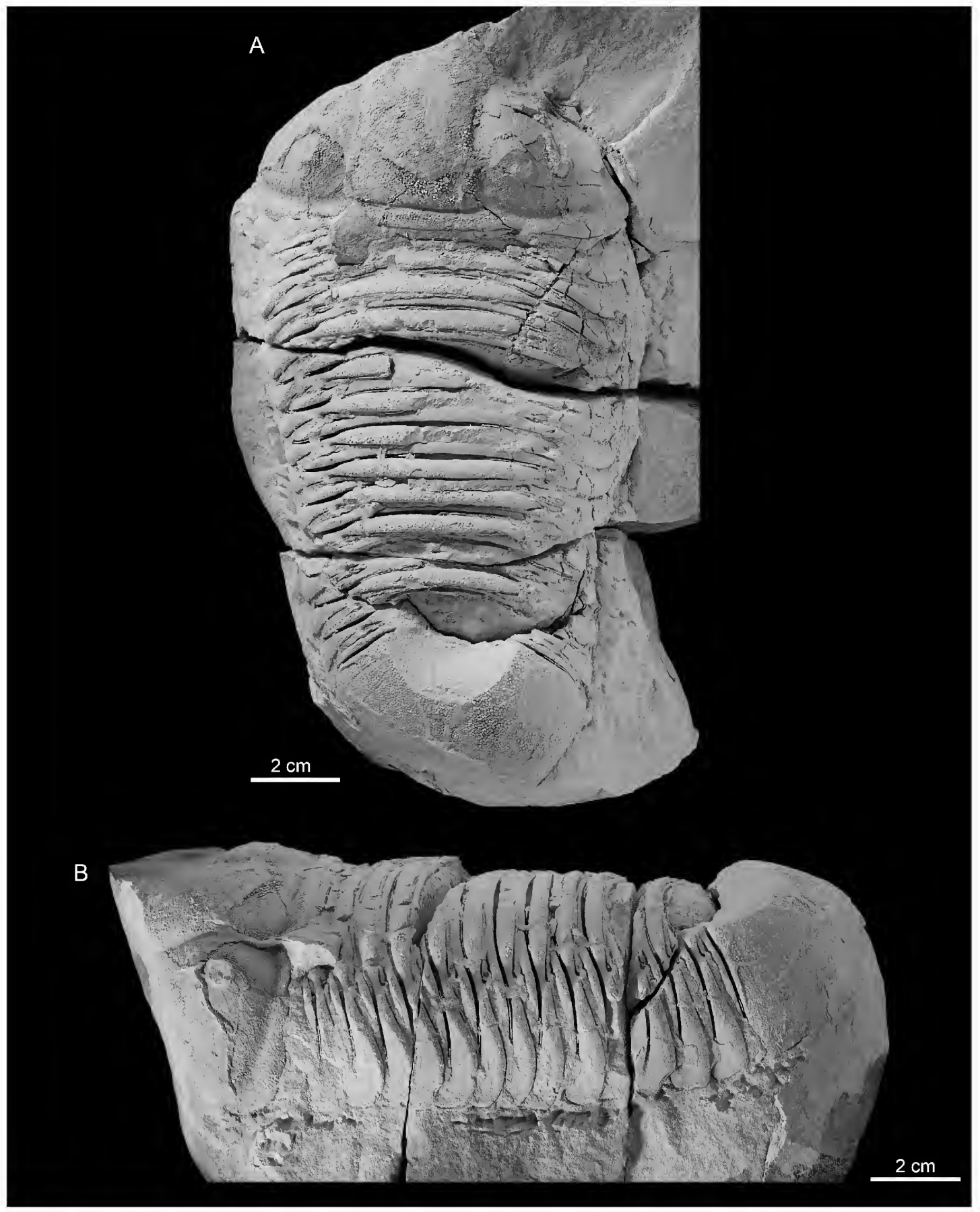

FIG. 2. Dipleura dekayi Green, 1832, CMCIP 77138, Floresta Formation, Gutierrez area, Colombia. Internal mold, dorsal (A) and lateral (B) views. 

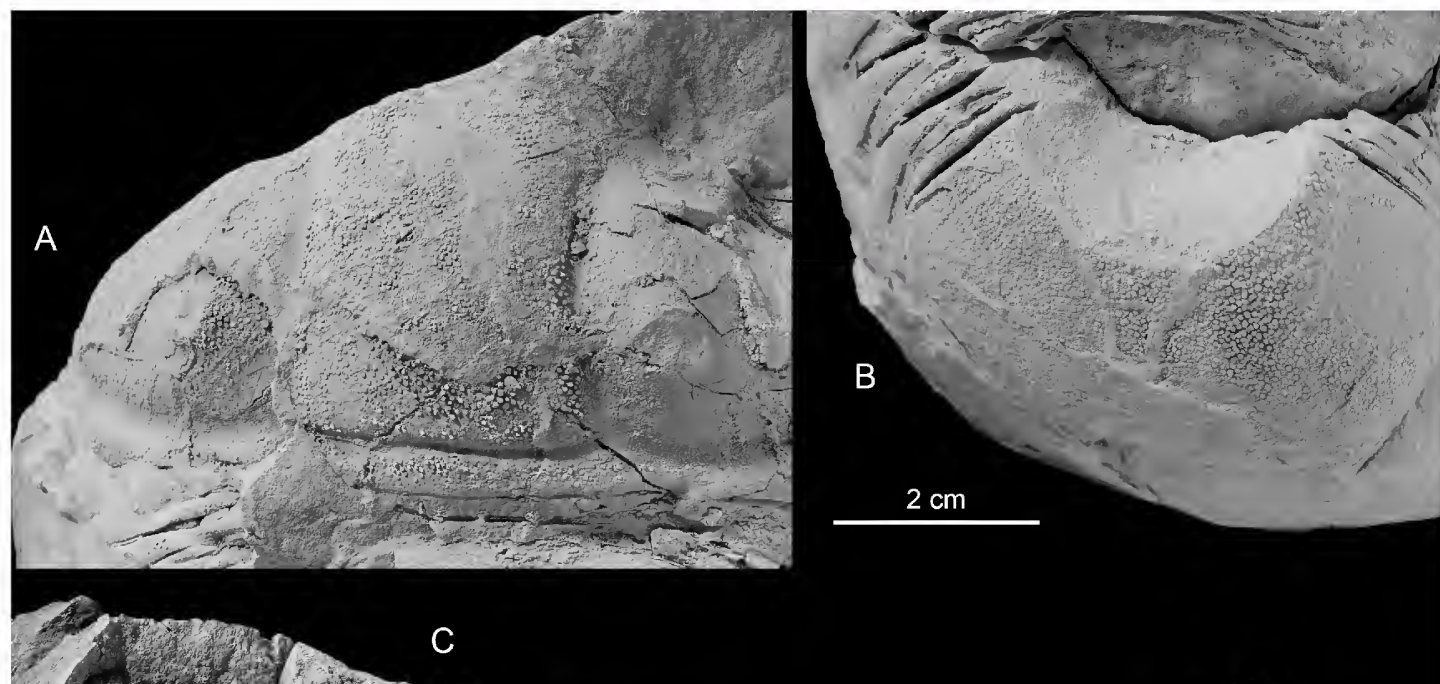

C
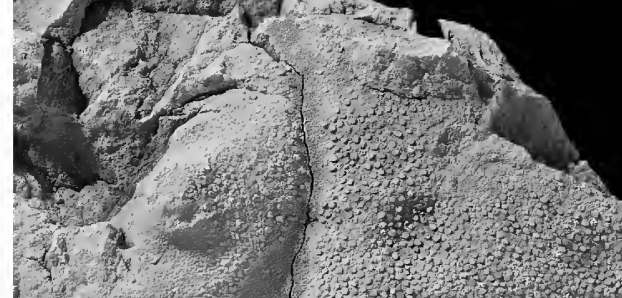

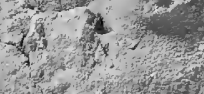
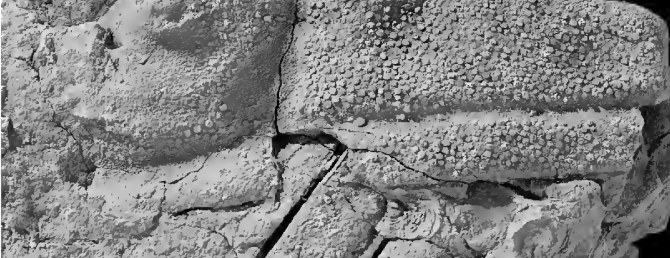

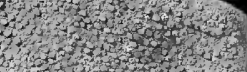
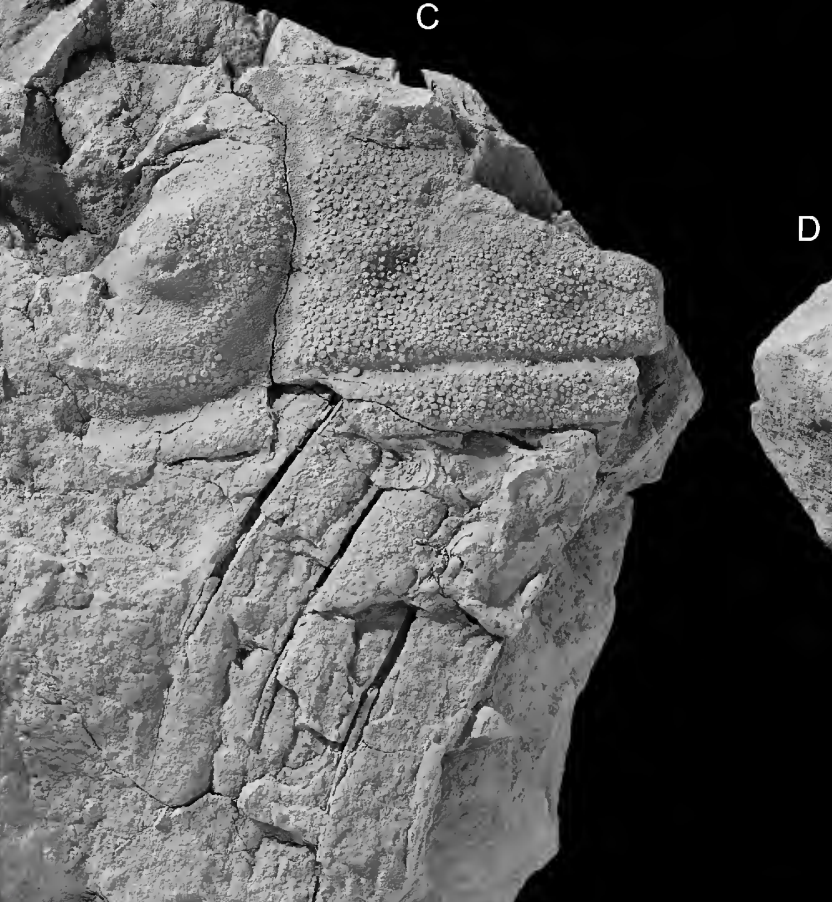

。

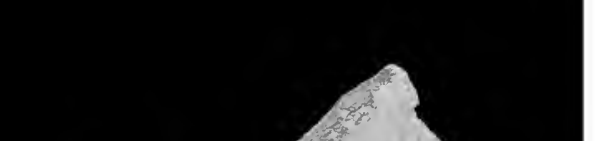


deep articulating furrow that curves smoothly backward and runs into the pleural furrow abaxially; the latter obliquely crosses the pleura and shallows distally.

The pygidium is convex (tr.), apparently semielliptical in outline, although its posterior end is not preserved. The anterior margin describes a forward curve, but it is incomplete medially. The axis is not defined on the preserved parts of the pygidium and there are almost no traces of trilobation, segmentation, or annulation, apart from one or two weakly indicated pleural furrows on the left side of the pygidium.

The exoskeleton is covered by vertical "tubulipores" (sensu Hall and Clarke, 1888; Stumm, 1953), apparently representing raised areas of matrix inside pits or tubules within the exoskeleton, creating a tubercle-like appearance on internal and external molds. These are denser on the most prominent portions of the cephalon, thorax axial rings, and especially on the pygidium (fig. 3A, B).

\section{DISCUSSION}

Until now, the type species Dipleura dekayi was unequivocally recognized only in North America, including New York (Green, 1832; Hall and Clark, 1888; Whiteley et al., 2002), Michigan (Stumm, 1953) and Ontario, Canada (Ludvigsen, 1979). With the exception of the Colombian material referred to Dipleura cf. dekayi by Morzadec et al. (2015), other records of the genus from South America have been referred to two other species, one from Argentina ( $D$. kayseri Thomas, 1905) and the other from Bolivia (D. boliviensis Wolfart, 1968).

The specimens described here from the Floresta Formation of Colombia resemble Dipleura dekayi from the Hamilton Group (Devonian of the United States) in certain respects, including: the subtriangular shape of the cephalon, an almost rectangular glabella with obsolete lobation; thorax with very faint trilobation; and the pygidium with obsolete axial furrows and very indistinct trilobation and segmentation.

By contrast, the Colombian material differs from other South American Dipleura species (D. boliviensis from Bolivia and D. kayseri from Argentina) as follows: In D. boliviensis, the glabellar margins are more concave laterally than in $D$. dekayi and become narrower (tr.) anteriorly; the cheeks are more inflated (this is not considered an artifact of the fossilization, because the fossils are preserved in three dimensions and do not show evidence of deformation). In $D$. kayseri, the pygidium is more triangular than in D. dekayi (where it is apparently semielliptical), has more distinct segmentation, and bears approximately 12 distinct axial rings.

The genus Dipleura has a wide geographic distribution in the Lower and Middle Devonian. In Europe, the genus is known from France (D. lanvoiensis Morzadec, 1969; D. sp.; Morzadec, 1983), Germany (D. laevicaudata; Quenstedt, 1852, as Homalonotus), Poland (D. praecox; Tomczykowa, 1975), and Spain (D. iberica and D. sp. A Wenndorf, 1990). Additional records of the genus include D. sp. from Africa (Morocco; Richter and Richter, 1943), and D. garrati from Australia (Sandford, 2005). Dipleura fornix Haas, 1968, from Turkey has been reassigned by Sandford (2005) to a new genus Wenndorfia. 
At present, Dipleura is considered a cosmopolitan taxon, with an almost worldwide distribution. Although the type species $D$. dekayi has a more restricted distribution, the present paper expands its range beyond North America. Its occurrence in Colombia nevertheless corroborates the biogeographical affinity of this area with the North Eastern Americas Realm.

\section{ACKNOWLEDGMENTS}

The author thanks D. Holloway (Museum of Victoria, Australia) and an anonymous reviewer for their comments and suggestions, which greatly improved the manuscript. Thanks are also extended to: S. Thurston (American Museum of Natural History), for making the maps and the photos; D. Meyer (University of Cincinnati), for lending the material to study; and J. Maisey (American Museum of Natural History), for his encouragement, always.

\section{REFERENCES}

Barrett, S.F. 1988. The Devonian system in Colombia. In N.J. McMillan, A.F. Embry, and D.J. Glass (editors), Devonian of the world. Second International Symposium on the Devonian System, vol. 1: 705-719. Calgary: Canadian Society of Petroleum Geologists.

Barrett, S.F. and P.E. Isaacson. 1988. Devonian paleogeography of South America. In N.J. McMillan, A.F. Embry, and D.J. Glass (editors), Devonian of the world. Second International Symposium on the Devonian System, vol. 1: 655-667). Calgary, Canada. Canadian Society of Petroleum Geologists.

Boucot, A.J. 1975. Evolution and extinction rate controls. Developments in Paleontology and Stratigraphy 1. Amsterdam: Elsevier, 427 pp.

Boucot, A.J., and Gray, J. 1979. Epilogue: a Paleozoic Pangaea? In J. Gray and A.J. Boucot (editors), Historical biogeography, plate tectonics, and the changing environment: 465-484. Corvallis: Oregon State University Press.

Caster, K.E. 1939. A Devonian fauna from Colombia. Bulletins of American Paleontology 24 (83): 1-218.

Caster, K.E. 1942. The age and relations of Colombian Devonian strata. In P.H. Oehser (editor), Proceedings of the Eighth American Scientific Congress held in Washington, May 10-18, 1940, vol. 4: 27-67. Washington, D.C.: Department of State.

Chapman, E.J. 1890. Some remarks on the classification of the trilobites as influenced by stratigraphical relations: with outline of a new grouping of these forms. Transactions of the Royal Society of Canada 7: 113-120.

Cooper, M.R. 1982. A revision of the Devonian (Emsian-Eifelian) Trilobita from the Bokkeveld Group of South Africa. Annals of the South African Museum 89: 1-173.

Forero, A.S. 1970. Estratigrafía del precretácico en el flanco occidental de la Serranía de Perijá. Geologia Colombiana 7: 1-77.

Green, J. 1832. A monograph of the trilobites of North America: with coloured models of the species. Philadelphia: Joseph Brano. 94 pp.

Haas, W. 1968. Trilobiten aus dem Silur und Devon des Bithynien (NW-Türkei). Palaeontographica Abteilung A 130: 60-207.

Hall, J., and J.M. Clarke. 1888. Descriptions of the trilobites and other Crustacea of the Oriskany, Upper Helderberg, Hamilton, Portage and Chemung, and Catskill Groups. Paleontology of New York 7. New York: New York State Geological Survey, 236 pp. 
Kozłowski, R. 1923. Faune dévonienne de Bolivie. Annales de Paléontologie 12: 1-112.

Ludvigsen, R. 1979. Fossils of Ontario. Part 1, the trilobites. Royal Ontario Museum, Life Sciences Miscellaneous Publications: 1-96.

McNair, A.H. 1940. Devonian Bryozoa from Colombia. Bulletins of American Paleontology 25 (93): 1-34.

Milne Edwards, H. 1840. Histoire naturelle des crustaces, comprenant l'anatomie, la physiologie et la classification des ces animaux. Tome troisième. Paris: Librairie encyclopedique de Roret, 638 pp.

Morales, P.A. 1965. A contribution of the knowledge of the Devonian faunas of Colombia. Universidad Industrial de Santander (Colombia). Boletin de Geologia 19: 51-109.

Morzadec, P. 1969. Le Dévonien de la rive nord de la rivière du Faou (Finistère). Étude stratigraphique. Étude des trilobites. Bulletin de la Société Géologique et Minéralogique de Bretagne 1968: 1-58.

Morzadec, P. 1983. Trilobites du Devonien (Emsian - Famennien) de la rade de Brest (Massif Armoricain). Palaeontographica Abteilung A 181: 103-184.

Morzadec, P., M. Mergl, C. Villarroel, P. Janvier, and P.R. Racheboeuf. 2015. Trilobites and inarticulate brachiopods from the Devonian Floresta Formation of Colombia: a review. Bulletin of Geosciences 90 (2): 1-28.

Nance, R.D., and U. Linnemann. 2008. The rheic ocean: origin, evolution and significance. GSA Today 18 (2): 4-12.

Quenstedt, F. 1852. Handbuch der Petrefaktenkunde, 2nd ed. Tübingen: H. Laupp.

Richter, R., and E. Richter. 1943. Studien im Paläozoikum der Mittelmeer-Länder. 4a. Trilobiten aus dem Devon von Morokko, mit einem Anhang über Arten des Rheinlands. Senkenbergiana 26: 116-199.

Salter, J. W. 1861. On the fossils from the high Andes, collected by David Forbes esq., FRS FGS. Quarterly Journal of the Geological Society of London 17: 62-73.

Sandford, A. C. 2005. Homalonotid trilobites from the Silurian and Lower Devonian of south-eastern Australia and New Zealand (Arthropoda: Trilobita: Homalonotidae). Memoirs of Museum Victoria 62 (1): 1-66.

Stumm, E. C. 1953. Trilobites of the Devonian Traverse Group of Michigan. Contribution from the Museum of Paleontology, University of Michigan 10 (6): 101-157.

Swinnerton, H. H. 1915. Suggestions for a revised classification of trilobites. Geological Magazine 6 (2): 487-496, 538-545.

Thomas, I. 1905. Neue Beiträge zur Kenntniss der devonischen Fauna Argentinien. Zeitschrift der Deutschen Geologischen Gesellschaft 57: 233-290.

Tomczykowa, E. 1975. The trilobite subfamily Homalonotinae from the Upper Silurian and Lower Devonian of Poland. Acta Palaeontologica Polonica 20: 3-46.

Wenndorf, K.-W. 1990. Homalonotinae (Trilobita) aus dem rheinischen Unter-Devon. Palaeontographica Abteilung A 211: 1-184.

Whiteley, T.E., G.J.Kloc, and C.E. Brett. 2002. Trilobites of New York, an illustrated guide. Ithaca, NY: Cornell University Press, 203 pp.

Wolfart, R. 1968. Die Trilobiten aus dem Devon Boliviens und ihre Bedeutung für Stratigraphie und Tiergeographie. In R. Wolfart and A. Voges (editors), Beiträge zur Kenntnis des Devons von Bolivien. Beihefte zum Geologischen Jahrbuch 74: 5-201. 